\title{
O ESTUDO DA CLASSE INSECTA NO ENSINO DE CIÊNCIAS E BIOLOGIA
}

\author{
Sebastião do Nascimento BATISTA ${ }^{1}$; Eliel Souza de OLIVEIRA ${ }^{2}$; Priscilla Morgana \\ Guimarães de Figueiredo CRUZ $^{3}$
}

\begin{abstract}
${ }^{1}$ Licenciado em Ciências Biológicas (UniAGES) e especialista em ensino de Biologia (UCAM-Pró Saber) ${ }^{2}$ Licenciado em Ciências Biológicas (UniAGES) e especialista em Docência no Ensino Superior (UCAM-Pró Saber) ${ }^{3}$ Mestre em Ecologia e Conservação pelo Programa de Pós-graduação em Ecologia e Conservação (PPEC-UFS)

E-mail principal: sebastiaonb@hotmail.com
\end{abstract}

DOI: $10.47094 /$ ICONECBIO.2020/2

Introdução: Os insetos compõem a maior classe do reino animal e possui diversas interações com outros organismos, inclusive com o ser humano. No ensino de Ciências e Biologia na educação básica, o estudo desses invertebrados possibilita a compreensão crítica sobre possíveis problemas e reflexão quanto a melhor forma de explorá-los como aliados à vida humana. Objetivo: Averiguar como o ensino de Ciências e Biologia podem contribuir para que os discentes entendam as relações existentes entre os insetos e o homem. Metodologia: Abordagem qualitativa, de natureza básica, de caráter exploratório e descritivo, com o uso de revisão bibliográfica e levantamento de dados. Foi realizado aplicações de questionários aos discentes do $8^{\circ}$ ano do ensino fundamental e $3^{\text {a }}$ série do ensino médio; e aos docentes que lecionam as disciplinas de Ciências ( $7^{\circ}$ ano) e Biologia ( $2^{\mathrm{a}}$ série). Também foi feita a análise de livros didáticos de Ciências ( $7^{\circ}$ ano) e Biologia ( $2^{\mathrm{a}}$ série). Resultados: Os livros didáticos abordam que os insetos são importantes e mantêm relações com o ser humano, sendo um recurso didático satisfatório. Os docentes ressaltam a importância do assunto para desconstruir ideias estereotipadas quanto aos insetos. Já os alunos carecem de percepção concreta sobre os insetos, sobretudo, a relação com o ser humano. Considerações finais: As referidas disciplinas são privilegiadas no emprego de métodos e estratégias diversificadas e contêm vastas possibilidades de aproximar o conhecimento científico ao cotidiano dos discentes, sendo uma importante via para relacionar os insetos com o ser humano.

Palavras-chave: Ensino. Ciências/Biologia. Insetos.

Área Temática: Ensino de Ciências e Biologia. 